\title{
BERNARD OF LUBLIN (BERNARDUS LUBLINIUS) AND HIS FICINIAN ANTHOLOGY: SOME OBSERVATIONS ${ }^{* *}$
}

Perhaps the most significant trace of the fortuna of Marsilio Ficino in early Renaissance Poland is the philosophical anthology containing some of his Latin translations of hermetic and Platonic dialogues which was compiled by Bernard of Lublin (Bernardus Lublinius), a Polish humanist and writer who was active at the turn of the XV and XVI centuries. This anthology is transmitted in a unique manuscript, presently MS 1117, in the collections of the Library of the Polish Academy of Arts and Sciences in Cracow.

The manuscript, written most probably by the hand of Bernard himself, contains extensive excerpts from Latin translations of more than 40 works of ancient Greek philosophy: the hermetic writings that circulated in the XV century (Asclepius in the anonymous Latin version, and Pimander translated by Marsilio Ficino), Plato's dialogues (excerpted from Ficino's Platonis Opera - the second and most extensive part of the manuscript) and Aristotle's moral and natural works (in the Latin translation by Leonardo Bruni and Johannes Argyropoulos). Because of its author, who was an important writer and humanist that left us, among others, one of the first printed books to be written in Polish (Raj duszny - Little Garden of the Soul), and also on account of its content, the Cracow manuscript is considered to be a valuable source documenting a typically humanist interest in philosophy, especially the Platonic and Neoplatonic one, in Poland at the beginnings of the XVI century.

Bernard's anthology remained unnoticed by Polish scholars for a long time, i.e. until Paul Oskar Kristeller drew Juliusz Domański's attention to it. Consequently, Bernard's codex was introduced to scholarly circulation, and was soon studied by Domański and Janusz Gruchała ${ }^{1}$. Particularly the latter

* Prof. dr hab. Włodzimierz Olszaniec - director of the Institute of Classical Studies at the University of Warsaw; e-mail: w.olszaniec@uw.edu.pl.

** I was able to prepare this article for publication thanks to a grant from the National Science Centre (DEC-2011/01/B/HS2/02082).

${ }^{1}$ Cf. J. Domański, La fortuna di Marsilio Ficino in Polonia nei secoli XV e XVI, in: Marsilio Ficino e il ritorno di Platone. Studi e documenti, a cura di G.C. Garfagnini, Firenze 1986, 565-586 (reprinted in Polish as: Losy Marsilia Ficina w Polsce w XV i XVI wieku, w: J. Domański, Philosophica - Paraphilosophica - Metaphilosophica. Studia i szkice z dziejów myśli dawnej, Kraków 
scholar has provided researchers with a thorough and detailed description of the codex in an article published in 1988 in which he made a number of penetrating observations concerning, among others, the sources of the anthology, its composition and possible importance.

Domański's and Gruchała's studies prepared the grounds for an edition of Bernard's work. Nevertheless, the anthology has not been published critically to date. It seems that this is due to two substantial reasons: the first is the huge amount of effort needed to prepare the edition. The manuscript, though inconscpicuous (its dimensions are only $16 \times 11 \mathrm{~cm}$ ), contains as many as 252 folios filled with very fine writing; in addition, its margins are covered with numerous notes which are often difficult to read, the total number of which considerably exceeds two thousand. The second reason is that the text transmitted by the manuscript is a collection of excerpts, and as such it can seem secondary and thus little interesting ${ }^{2}$. These are the factors that have most probably discouraged any would-be editors.

In this article I am going to present selected results of my studies on the first part of Bernard's anthology, mostly Ficinian ${ }^{3}$. These concern two problems. The first are the sources of Bernard's excerpts from the Latin versions of hermetic and Platonic writings - the printed editions which Bernard could have had at his disposal. I suggest slight corrections to Gruchała's otherwise accurate observations and I confirm some of his suppositions. The second question is the method of compilation. I argue that Bernard's work is not just a collection of loosely connected quotations, copied from their sources without any changes, but that these quotations have undergone various operations of the author-compiler, the aim of which was to arrange them into a coherent whole.

\section{SOURCES OF THE COMPILATION}

1. Hermetic dialogues. It has been pointed out that a combination of $A s-$ clepius and Pimander in the same printed edition was relatively rare ${ }^{4}$. Since Bernard wrote down his manuscript in 1505 - which is the terminus ante quem in this case - he could only have made use of the Paris edition printed by Henricus Stephanus in the same year ${ }^{5}$. This hypothesis, put forward by Gruchała, can be supported by the fact that a native of Cracow, Jan Schilling (Iohannes

2008, 369-389); J. Gruchała, Biernata z Lublina antologia filozoficzna z poczqtku XVI w. (Hermes Trismegistos - Platon - Arystoteles), „Biuletyn Biblioteki Jagiellońskiej” 38 (1988) 63-77.

2 J. Gruchała (Biernata z Lublina antologia filozoficzna, p. 66) considers Bernard's work to be "a dry extract that would be difficult to digest if it weren't for the carefully elaborated index" ("suchy ekstrakt, który trudno by było strawić, gdyby nie pracowicie sporządzony indeks").

${ }^{3}$ These results will also be presented in an introduction to the critical edition of Bernard's antology that I have in preparation.

${ }^{4}$ Cf. Gruchała, Biernata z Lublina antologia filozoficzna, p. 70.

${ }^{5}$ Parisiis in officina Henrici Stephani, recognitoribus mendasque ex officina eluentibus Ioanne Solido Cracouiensi et Volgacio Pratensi [...] M.D.V. 
Solidus), was involved in the preparation of this edition. A systematic comparison of the readings of Bernard's MS with Stephanus' edition, however, excludes such a possibility. Apart from slight and unimportant differences that could be explained as Bernard's conscious corrections, or errors in copying (for example Bernard (f. 21r): actum eundem habent, Ed. 1505: eundem actum habent; Bernard (f. 21r): deficiens ac indignum est; Ed. 1505: deficiens at indignum est; Bernard (f. 12v): Quod tamen delinquunt, Ed. 1505: Quot tamen delinquunt), one finds two more striking differences: Bernard (f. 1r): Naturam per species imaginans, Ed. 1505: Naturam per species efficians; Bernard (f. 15v): Sermonem quidem singulis hominibus deus impertit, Ed. 1505: Sermonem quidem singulis hominibus deus impartivit.

My research on the source of Bernard's excerpts from Asclepius and Pimander has not brought about any decisive results to date. The author probably relied on more than one source, but only further studies on the textual tradition of both hermetic dialogues will allow us to resolve the question.

2. Plato's dialogues in the Latin version of Marsilio Ficino. In this part of his MS, Bernard could have made use of one of the two printed editions of the Platonis Opera Omnia which were published before 1505, i.e. Florentiae, 1484, Laurentius Venetus (Lorenzo de Alopa) and Venetiis 1491, Bernardinus de Choris - Simon de Luere. The first of these editions contains a group of flaws that were noticed and corrected by the translator himself - Marislio Ficino. The most striking of these defects is a huge lacuna in the initial part of the Meno. On fol. 9, col. 4, after the last word - "si" - a long passage of the text is missing, while it is found in the Venetian edition where it occupies almost one and a half columns. Since excerps from this passage are quoted by Bernard in his anthology (f. 37r.: "An potest quisquam civitatem vel domum aut aliquid aliud recte disponere, nisi temperate sive prudenter ac iuste disponat? Utrisque igitur tam vir quam mulier indiget, si boni futuri sint, temperantia scilicet atque iusticia. Universi igitur homines eadem ratione boni sunt, nam eorundem participatione boni semper efficiuntur"), the Polish writer must have had the Choris-Luere edition at his disposal.

\section{BERNARD'S COMPILATION METHOD}

A close analysis of Bernard's method of compilation and a comparison of his collection with its sources allows us to state that the humanist not only carefully selected passages from these sources but also arranged them in such a way that they created a consistent entirety. The most frequent - and obvious - operation aiming to reach this consistency were the various syntactical transformations that enabled him to combine phrases excerpted from different places of the quoted source. I will now illustrate this method with selected examples. 
Let us start with the following example:

Pseudo-Plato, Hipparchus 225a

Ficino: "So. Et qui sunt lucri cupidi? Hip. Mihi quidem videntur, qui lucrandum putant ex rebus nulla existimatione dignis".

Bernard (f. 36r): "Lucricupidi mihi quidem videntur, qui lucrandum putant ex rebus nulla existimatione dignis".

As it can be noticed, Bernard transformed Socrates' question and Hipparchus' answer into an indicative clause. One may object that by removing the dialogue - the distinctive feature of Plato's style - Bernard has, in a way, impoverished the quoted original. If we assume, however, that the author's goal was to produce a coherent collection of adages containing the wisdom of Greek philosophy, this kind of tranformation becomes obvious.

Omission of the names of the interlocutors is justified for the same reason:

Plato, Meno $100 \mathrm{~b}$

Ficino: "So. Ex hac itaque ratione, o Menon, divina sorte virtus adesse, cuicunque adsit, apparet".

Bernard (f. 38v): "Hac itaque ratione divina sorte virtus adesse, cuicunque adsit, apparet".

Innumerous cases of this procedure are found throughout the anthology.

Similar is the goal of the numerous syntactical transformations that Bernard resorts to on almost every page of the Platonic part of his collection, for example:

Pseudo-Plato, Hipparchus 228c

Ficino: "So. [...] ratus minime oportere alicui sapientiam invidere, quippe qui honestus ac bonus existeret".

Bernard (f. 36r): "Minime opportere alicui sapientiam invidere, quippe qui honestus ac bonus existeret".

Bernard separates the needed adage from a longer phrase, ignoring the dependence of the perfective ratus and the tense of the subjunctive "existeret".

Interest in aphoristic expressions also justifies the shortenings of the quoted passages and omissions of content that the compiler considered as irrelevant for his purpose, for example:

Pseudo-Plato, Minos 314c

Ficino: "So. Nonne sapientes sapientia sapientes sunt? Min. Ita. Et iusti, iustitia iusti? Min. Prorsus". So. "Ergo et legitimi lege legitimi? Min. Nempe. So. Iniqui autem iniquitate iniqui? Min. Certe. So. Legitimi vero iusti? Min. Ita. So. Iniqui autem iniusti? Min. Iniusti".

Bernard (f. 42v): "Legittimi vero iusti, iniqui autem iniusti". 
As we can see, the exchange of phrases between Socrates and Minos was transformed into a short adage containing the main thought of this conversation.

In order to avoid the impression that his text is a collection of separate excerpts, Bernard removes (or, less frequently, introduces) various conjunctions and particles, for example:

Ficino, Argumentum in Amatores: "Est autem philosophi offitium divina nosse, gubernare humana".

Bernard (f. 36r): "Philosophi est officium divina nosse, gubernare humana".

Thanks to this operation he obtains, again, a phrase that can function as an adage and not as a passage separated from a longer discourse.

All transformations illustrated above are frequent not only in the "Ficinian" part of Bernard's anthology but also in the last, Aristotelic part of the manuscript as well. They have, let us repeat, one principal goal. The authorcompiler wishes to avoid the impression that his work is a harsh collection of chaotically excerpted and roughly connected quotations and he tries, instead, to produce an elegant anthology of Greek philosophical thought. While combining his excerpts, Bernard did not manage to avoid certain misunderstandings, syntactical errors and a number of minor flaws, but his text is virtually free from the ordinary errors of inattention. One might say that if Bernard of Lublin was a professional copyist, he would be an excellent one.

\section{BIERNAT Z LUBLINA (BERNARDUS LUBLINIUS) I JEGO ANTOLOGIA FICINIAŃSKA: KILKA UWAG}

\section{(Streszczenie)}

Niniejszy artykuł ma w zamierzeniu naświetlić grupę problemów zwiazanych $\mathrm{z}$ antologią tekstów filozoficznych przekazaną przez autograficzny rękopis Biernata (Bernarda) z Lublina. Autor artykułu skupia się na dwóch zagadnieniach: problemie źródeł wypisów Biernata z łacińskich przekładów dialogów hermetycznych i dzieł Platona (w thumaczeniu Marsilia Ficina) oraz metodzie kompilacyjnej zastosowanej przez polskiego pisarza. W zamierzeniu autora spostrzeżenia zawarte $\mathrm{w}$ artykule mają być użyteczne w przyszłych badaniach nad antologia, w tym w przygotowywanej edycji krytycznej.

Key words: Bernard of Lublin, Marsilio Ficino, Renaissance Latin translations.

Słowa kluczowe: Biernat z Lublina, Marsilio Ficino, łacińskie przekłady w renesansie. 


\section{BIBLIOGRAPHY}

\section{Sources}

Opera Platonis Marsilio Ficino interprete, impressum Florentiae per Leonardum Venetum, MCCCCLXXXIV.

Platonis opera Latina Marsilio Ficino interprete, impressum Venetiis per Bernardinum de Choris de Cremona et Simonem de Luero impensis Andreae Torresani de Asula, MCCCCLXXXXI.

Mercurii Trismegisti liber De sapientia et potestate Dei. Asclepius. Eiusdem Mercurii liber De voluntate diuina. Item Crater Hermetis, Parisiis in officina Henrici Stephani, recognitoribus mendasque ex officina eluentibus Ioanne Solido Cracouiensi et Volgacio Pratensi [...] MDV.

\section{Literature}

Domański J., La fortuna di Marsilio Ficino in Polonia nei secoli XV e XVI, in: Marsilio Ficino e il ritorno di Platone. Studi e documenti, a cura di G.C. Garfagnini, Firenze 1986, 565-586.

Domański J., Losy Marsilia Ficina w Polsce w XV i XVI wieku, in: idem, Philosophica - Paraphilosophica - Metaphilosophica. Studia i szkice z dziejów myśli dawnej, Kraków 2008, 369-389.

Gruchala J., Biernata z Lublina antologia filozoficzna z poczatku XVI w. (Hermes Trismegistos - Platon - Arystoteles), „Biuletyn Biblioteki Jagiellońskiej” 38 (1988) 63-77. 